\section{Pigment Concentrations among Heat-tolerant Turfgrasses}

\author{
Mark G. Lefsrud ${ }^{1}$ \\ Bioresource Engineering Department, McGill University, 21111 Lakeshore \\ Boulevard, Ste-Anne-de-Bellevue, Quebec H9X 3V9, Canada
}

John C. Sorochan and Dean A. Kopsell

Plant Sciences Department, The University of Tennessee, 2431 Joe Johnson Dr., Knoxville, TN 37996-4561

\section{J. Scott McElroy \\ Department of Agronomy and Soils, Auburn University, 202 Funchess Hall, Auburn, AL 36849-5412}

Additional index words. $\beta$-carotene, carotenoids, chlorophyll $a$ and $b$, HPLC, lutein, seasonality, Poa pratensis L., Festuca arundinacea Schreb

\begin{abstract}
Heat-tolerant bluegrass varieties were developed to resist dormancy and retain pigmentation during heat stress events. The objective of this study was to investigate the influence of grass species, nitrogen $(N)$ fertilization, and seasonality on the accumulation patterns of lutein, $\beta$-carotene, and chlorophyll $a$ and $b$ in the leaf tissues of turfgrass. The heat-tolerant bluegrass cultivars Dura Blue and Thermal Blue (Poa pratensis L. $\times$ Poa arachnifera Torr.), Apollo kentucky bluegrass (Poa pratensis L.), and Kentucky 31 tall fescue (Festuca arundinacea Schreb.) were compared for the accumulation of plant pigments. Evaluations were conducted over 2 consecutive years (Years 4 and 5 after establishment) during two different seasons (spring and summer) and under varying $\mathbf{N}$ fertilization. Fertilizer applications of 5,14 , and $27 \mathrm{~g} \mathrm{~N} / \mathrm{m}^{2} /$ year resulted in a significant positive correlation for the accumulation of leaf blade lutein and chlorophyll $a$ and $b$, but not for $\beta$-carotene. The accumulation of the four measured plant pigments among the grasses was significantly different with 'Apollo' having the largest concentration of pigments followed by 'Dura Blue', 'Thermal Blue', and finally 'Kentucky 31'. Specifically, when comparing the cultivars Apollo and Kentucky 31, the pigment levels decreased $27 \%, 26 \%, 26 \%$, and $23 \%$ for lutein, $\beta$-carotene, and chlorophyll $a$ and $b$, respectively. The interesting observation of the analysis of the grass pigment concentrations was that the least reported heat-tolerant cultivar in our study ('Apollo') had the largest measured pigment concentrations.
\end{abstract}

Kentucky bluegrass (Poa pratensis L.) and tall fescue (Festuca arundinacea Schreb.; syn., Lolium arundinaceum Darbyshire) are cool-season grasses commonly used for lawns in temperate regions of North America. However, these grasses can be exposed to heat stress during the growing season in temperate regions. During high stress events, kentucky bluegrass can become dormant and lose pigmentation (Beard, 1973; $\mathrm{Su}$ et al., 2007). Tall fescue has increased heat and drought tolerance, but it is usually not selected over the finer textured kentucky bluegrass. Researchers have been developing heat-tolerant bluegrasses through hybridization of kentucky bluegrass and texas bluegrass (Poa arachnifera Torr.). Texas bluegrass has similar visual characteristics

Received for publication 13 Jan. 2010. Accepted for publication 19 Feb. 2010.

This material is based on work supported by the Tennessee Turfgrass Association, the Scotts Company (Marysville, Ohio), and the University of Tennessee Agricultural Experiment Station.

${ }^{1}$ To whom reprint requests should be addressed; e-mail sorochan@utk.edu. as kentucky bluegrass and, with higher temperature tolerance, can be grown as a substitute for kentucky bluegrass in warmer climatic regions but is poorly adapted for temperate and transition regions (Read et al., 1994). The resultant hybrid heat-tolerant bluegrass $(P$. pratensis $\times P$. arachnifera $)$ is reported to have the ability to survive heat stress events (Su et al., 2007) and, from visual comparison, may be able to maintain tissue pigmentation [carotenoids and chlorophylls (Chl)] throughout the growing season ( $\mathrm{Su}$ et al., 2007; Teuton et al., 2007). However, nothing in the literature has been reported on the pigment concentration independent of the stress events and during the stress events.

Carotenoids are lipid-soluble yellow, orange, and red pigments synthesized in higher plants, fungi, algae, and bacteria. Carotenoids function to help harvest light energy during photosynthesis and to dissipate excess energy before damage occurs. Within the thylakoid membranes of chloroplast organelles, carotenoids are found bound to specific protein complexes of the photosystems. Carotenoids are located in both the antenna pigments and the photosynthetic reaction center (Peng and Gilmore, 2003; Taiz and Zeiger, 1998). When the absorption of light radiation exceeds the capacity of photosynthesis, excess excitation energy can result in the formation of triplet excited chlorophyll $\left({ }^{3} \mathrm{Chl}\right)$ and reactive singlet oxygen $\left({ }^{1} \mathrm{O}_{2}\right)$. Carotenoid pigments protect photosynthetic structures by quenching excited ${ }^{3} \mathrm{Chl}$ to dissipate excess energy (Tracewell et al., 2001) and binding ${ }^{1} \mathrm{O}_{2}$ to inhibit oxidative damage (Demmig-Adams et al., 1996; Tracewell et al., 2001). The carotenoid molecule then slowly releases this excess energy as heat and inhibits further oxidative damage. Carotenoids are also integral constituents of membranes (Peng and Gilmore, 2003; Taiz and Zeiger, 1998) and may be involved in structural stabilization of membranes and reduction of lipid peroxidation (Frank and Cogdell, 1996).

Carotenoid accumulation appears to be shaped by a plant species' physiological, genetic, and biochemical attributes as well as environmental growth factors such as light, temperature, and fertility (Kopsell et al., 2004; Kurilich et al., 1999; Lefsrud et al., 2005, 2006). Kurilich et al. (1999) reported genotypic differences among subspecies of Brassica oleracea L. (broccoli) accounted for $79 \%$ of the variance of $\beta$-carotene concentration, $82 \%$ of the variance of $\alpha$-tocopherol (vitamin E), and $55 \%$ of the variance of ascorbate (vitamin C). Therefore, it is critical to consider both genetic and environmental influences when determining plant carotenoid accumulation.

Nitrogen $(\mathrm{N})$ is critical in plant growth and development and is an essential component of amino acids, proteins, nucleic acids, and many enzymes. Plants grown under limited $\mathrm{N}$ levels have reduced $\mathrm{Chl} a$ and Chl $b$ pigments, resulting in stunted plants and characteristic leaf chlorosis (Marschner, 1995). Increased additions of $\mathrm{N}$ usually result in increased yield of crop plants (Hochmuth et al., 1999; Mills and Jones, 1996). However, toxicity from overapplication of $\mathrm{N}$ concentrations is possible but is not very common in turfgrass. Therefore, proper $\mathrm{N}$ management is critical for optimum plant performance.

Seasonality effects caused by increases in irradiance, photoperiod, temperature, and rainfall can directly influence the growth and photosynthetic rate of plants, resulting in increased production of carbohydrates and total biomass (Mills and Jones, 1996). Summergrown kale (Brassica oleracea L. var. acephala D.C.) had higher lutein and $\beta$-carotene concentrations than kale grown during winter months when light levels and photoperiod were reduced (de Azevedo and RodriguezAmaya, 2005).

Kentucky bluegrass is the major temperate weather turfgrass, but it becomes dormant and loses pigmentation during either individual or combined drought and heat stress events (Su et al., 2007; Teuton et al., 2007). With the development of heat-tolerant bluegrass cultivars, dormancy has become less of an issue and the grass is able to better retain 
more of its visual quality during stress conditions. However, it is unclear whether traditional and heat-tolerant turfgrasses are able to accumulate plant pigments (lutein, $\beta$-carotene, and Chls) over the growing season to allow the turfgrass to tolerate stress events. Therefore, the objective of this study was to determine the accumulation patterns of lutein, $\beta$-carotene, $\mathrm{Chl} a$, and $\mathrm{Chl} b$ in the leaf tissues of heat-tolerant and nonheat-tolerant turfgrass between turfgrass species, $\mathrm{N}$ fertility, and sampling time (during the spring and summer seasons).

\section{Material and Methods}

Turfgrass culture. The turfgrass cultivars were field-grown in Knoxville, TN (lat. $35.49^{\circ} \mathrm{N}$, long. $83.56^{\circ} \mathrm{W}$ ) with seeding occurring on 23 Oct. 2002. Establishment and maintenance was performed as outlined by Teuton et al. (2007) with only one tall fescue analyzed for this experiment. Kentucky bluegrass and tall fescue varieties were seeded at 100 and $300 \mathrm{~kg} \cdot \mathrm{ha}^{-1}$, respectively. Nitrogen was applied as urea and occurred as reported by Teuton et al. (2007). Turfgrasses were fertilized at the time of seeding and monthly thereafter until December with $\mathrm{N}$ applied at $2.4 \mathrm{~g} \cdot \mathrm{m}^{-2}$ to ensure adequate turfgrass density. Fertilization started in April of each year and included $\mathrm{N}$ applied at 5, 14, $27 \mathrm{~g} \mathrm{~N} / \mathrm{m}^{2} /$ year. The $5-\mathrm{g} \mathrm{N} / \mathrm{m}^{2}$ treatments were applied as $2.5 \mathrm{~g} \mathrm{~N} / \mathrm{m}^{2}$ in April and September. The $14-\mathrm{g} \mathrm{N} / \mathrm{m}^{2}$ treatments were applied as $2.3 \mathrm{~g}$ $\mathrm{N} / \mathrm{m}^{2}$ in April and May and $4.7 \mathrm{~g} \mathrm{~N} / \mathrm{m}^{2}$ in September and December. The 27-g N/m² treatments were applied as $6 \mathrm{~g} \mathrm{~N} / \mathrm{m}^{2}$ in April, May, June, July, September, and December. The grass cultivars tested included a tall fescue, 'Kentucky 31', a kentucky bluegrass, 'Apollo', and two $\mathrm{F}_{1}$ hybrids, 'Thermal Blue' (formerly HB-129) and 'Dura Blue' (formerly HB-329) (Scotts Company Inc., Marysville, $\mathrm{OH}$ ). The most heat-tolerant turfgrass in our study was 'Kentucky 31' and then 'Thermal Blue', 'Dura Blue', and finally 'Apollo' based on previous research by $\mathrm{Su}$ et al. (2007) and Teuton et al. (2007). The turfgrass and $\mathrm{N}$ treatment were separated into randomized complete blocks with three replications. Plots were not irrigated and standard mowing (7.5-cm mowing height) was performed once a week over the growing season.

Turfgrass was sampled on 10 Mar. and 31 July 2006 and 12 Mar. and 22 July 2007. These dates were chosen for measurement during the spring and summer seasons and replicated as close as possible for days after mowing (5 d). At sampling, the turfgrass was hand-cut with scissors, separated for only green tissue samples, and weighed for each of the three $\mathrm{N}$ treatments, four cultivars, and three replication combinations. Turfgrass samples were stored at $-80{ }^{\circ} \mathrm{C}$ before high-performance liquid chromatography analysis.

Carotenoid and chlorophyll determination. The turfgrass pigments were extracted and separated according to Kopsell et al. (2004), which is based on the method of Khachik et al. (1986). A frozen 0.25-g subsample was placed into a Potter-Elvehjem tissue grinder tube (Kontes, Vineland, NJ). A $0.8-\mathrm{mL}$ volume of the internal standard, ethyl- $\beta$-apo- 8 ' -carotenoate (Sigma Chemical Co., St. Louis, MO) and $2.5 \mathrm{~mL}$ of tetrahydrofuran stabilized with $25 \mathrm{mg} \cdot \mathrm{L}^{-1}$ 2,6-Di-tert-butyl-4-methoxyphenol were added to the grinding tube. The sample was homogenized in the tube with 25 insertions of the grinder pestle attached to a drill press (Model Craftsman 15 inch Drill Press; Sears Co., Hoffman Estates, IL) at $540 \mathrm{rpm}$ while immersed in ice. The tube was placed into a clinical centrifuge for $3 \mathrm{~min}$ at $500 \mathrm{~g}_{\mathrm{n}}$. The supernatant was removed with a Pasteur pipette, placed into a conical $15-\mathrm{mL}$ test tube, capped, and held on ice. The sample pellet was resuspended in $2 \mathrm{~mL}$ of tetrahydrofuran and homogenized with 25 insertions of the grinding pestle. The tube was centrifuged for $3 \mathrm{~min}$ at $500 g_{n}$ and the supernatant was collected and combined with the first extracted supernatant. The extraction procedure was repeated twice more until the supernatant was colorless. The pellet was discarded and the combined four supernatants were placed in a $40{ }^{\circ} \mathrm{C}$ water bath and reduced to $0.5 \mathrm{~mL}$ using $\mathrm{N}$ gas (N-EVAP 111; Organomatic Inc., Berlin, MA). A total of $2.5 \mathrm{~mL} \mathrm{MeOH}$ and $2 \mathrm{~mL}$ tetrahydrofuran were added to the sample, which was then vortexed and filtered through a $0.2-\mu \mathrm{m}$ polytetrafluoroethylene filter (Econofilter PTFE 25/20; Agilent Technologies, Wilmington, DE) using a 5-mL syringe (Becton, Dickinson and Company, Franklin Lakes, NJ) before high-performance liquid chromatography (HPLC) analysis.

High-performance liquid chromatography analysis. An HPLC unit with photodiode array detector (Agilent 1100; Agilent Technologies, Palo Alto, CA) was used for pigment separation. All samples were analyzed for carotenoid compounds using a Pronto SIL $5.0 \mu \mathrm{m} 250 \times 4.6-\mathrm{mm}$ column $\left(200-5-\mathrm{C}_{30}\right.$; Bischoff Chromatography, Leonberg, Germany) fitted with a $4 \times 3.0 \mathrm{~mm}, 7.0-\mu \mathrm{m}$ guard column compartment. The column was maintained at $30^{\circ} \mathrm{C}$ using a thermostatic column compartment. The eluent was $11 \%$ methyltert butyl ether, $89 \%$ methanol, $0.1 \%$ triethyamine in water $(\mathrm{v} / \mathrm{v})$. The flow rate was 1.0 $\mathrm{mL} \cdot \mathrm{min}^{-1}$ for $55 \mathrm{~min}$. Eluted compounds from a $10.0-\mu \mathrm{L}$ injection were detected at $453 \mathrm{~nm}$ (carotenoids and internal standard) and $652 \mathrm{~nm}$ (Chls) with data collected and integrated using 1100 HPLC ChemStation Software (Agilent Technologies). Peak assignment was performed by comparing retention times and line spectra obtained from the photodiode array detection with authentic standards (lutein from Carotenature, Lupsingen, Switzerland; $\beta$-carotene, $\mathrm{Chl} a$, and $\mathrm{Chl}$ $b$ from Sigma Chemical Co.). Recovery rates of ethyl- $\beta$-apo- 8 '-carotenoate during extraction were above $90 \%$.

Statistical analysis. The experimental design was a randomized complete block design repeated in time with analysis using the multivariate generalized linear model procedure using SPSS (Chicago, IL. Multivariate analysis of variance determined significance of the main effects of treatments, cultivar, sample time, and their interactions and post hoc tests were complete using Tukey's honestly significant difference.

\section{Results and Discussion}

Turfgrass fresh mass pigment accumulation was significantly influenced by grass cultivar, $\mathrm{N}$ treatment concentrations, and time of sampling with no significant interaction effect expressed from the statistical analysis. The four grass cultivars varied significantly in pigment accumulation for lutein $(P \leq 0.001), \beta$-carotene $(P \leq 0.001)$, Chl $a(P \leq 0.001)$, and Chl $b(P \leq 0.001)$. When the turfgrass cultivars were compared, 'Apollo' and 'Dura Blue' always had more of the four plant pigments than did 'Kentucky 31 ', and 'Apollo' always had more of all four of the plant pigments than 'Thermal Blue' (Table 1).

Differences among turfgrass cultivars resulted in varying accumulation levels of tissue lutein, $\beta$-carotene, and both Chls. Research by Bremer et al. (2003) showed that the tall fescue 'Dynasty' had the highest visual quality rating (National Turfgrass Evaluation Program) followed by the hybrid 'Thermal Blue', kentucky bluegrass 'Apollo', and finally the hybrid 'Dura Blue'. Under an irrigation treatment of $40 \%$ replacement of evapotransportation (severe drought), the top-rated grass for visual quality was still 'Dynasty' followed by 'Thermal Blue', 'Dura Blue', and finally 'Apollo'. However, Bremer et al. (2006) reported similar responses in the overall growth among the three turfgrasses, 'Thermal Blue',

Table 1. Tissue lutein, $\beta$-carotene, and chlorophyll $a$ and $b$ pigments expressed on a fresh mass (FM) basis for the kentucky bluegrass 'Apollo', two hybrid heat-tolerant bluegrass 'Thermal Blue' and 'Dura Blue', and tall fescue 'Kentucky 31 '.

\begin{tabular}{lcccr}
\hline & \multicolumn{4}{c}{ Pigment concn $(\mathrm{mg} / 100 \mathrm{~g}$ FM) } \\
\cline { 2 - 5 } Cultivar & Lutein & $\beta$-carotene & Chlorophyll $a$ & Chlorophyll $b$ \\
\hline Apollo & $55.5 \pm 2.5 \mathrm{a}$ & $24.0 \pm 1.3 \mathrm{a}$ & $514.7 \pm 25.0 \mathrm{a}$ & $168.4 \pm 6.9 \mathrm{a}$ \\
Dura Blue & $52.6 \pm 1.7 \mathrm{a}$ & $22.5 \pm 1.1 \mathrm{ab}$ & $478.8 \pm 22.0 \mathrm{ab}$ & $162.1 \pm 6.3 \mathrm{a}$ \\
Thermal Blue & $44.2 \pm 2.2 \mathrm{~b}$ & $20.2 \pm 1.3 \mathrm{bc}$ & $432.5 \pm 28.2 \mathrm{bc}$ & $139.9 \pm 8.8 \mathrm{~b}$ \\
Kentucky 31 & $40.5 \pm 2.1 \mathrm{~b}$ & $17.8 \pm 1.2 \mathrm{c}$ & $377.9 \pm 29.5 \mathrm{c}$ & $129.6 \pm 8.2 \mathrm{~b}$ \\
\hline
\end{tabular}

${ }^{\mathrm{z}}$ Data were combined over 2 years from three replications of three nitrogen treatments $\left(5,14\right.$, and $27 \mathrm{~g} / \mathrm{m}^{2} /$ year) and two seasons (spring and summer).

Mean values $\pm \mathrm{SE}$.

Tukey's HSD significance at $P \leq 0.05$. 
'Dura Blue', and 'Apollo', in a Kansas field study. Genetic variation for carotenoid accumulation can be found in a number of plants, including spinach (Spinacia oleracea L.) (Lefsrud et al., 2007), broccoli (Brassica oleracea L. var. italica Plenck) (Almela et al., 1991; Daood et al., 1996), and kale (Kopsell et al., 2004). Zhang et al. (2005) reported that when kentucky bluegrass was exposed to ultraviolet $\mathrm{B}$ irradiation, some cultivars accumulated Chls and carotenoids at a greater rate than others. The bluegrass cultivars that accumulated Chls at the greatest rate (darkest color) resulted in an improved tolerance to ultraviolet B light. In our current study, the level of ultraviolet light was not measured. Zhang et al. (2005) showed that genetics and cultivar can have a significant effect on pigment accumulation. McElroy et al. (2006) reported that for creeping bentgrass (Agrostis stolonifera L.), levels of $\beta$-carotene decreased with no change in lutein as irradiance increased. However, other carotenoids (zeaxanthin, antheraxanthin, and violaxanthin) increased in response to increased irradiance, which may be potentially attributable to selection efforts of more stress-tolerant varieties. An interesting observation of the analysis of the study was that the least reported heat-tolerant cultivar in our study, 'Apollo', had the highest measured pigment concentrations.

The $\mathrm{N}$ treatments also had a significant impact on pigment accumulation for lutein $(P=0.019)$, Chl $a(P=0.036)$, and $\mathrm{Chl} b(P=$ $0.021)$, but not for $\beta$-carotene $(P=0.051)$. $27 \mathrm{~g} \mathrm{~N} / \mathrm{m}^{2} /$ year consistently had the highest levels of measured pigments with a reduction for $14 \mathrm{~g} \mathrm{~N} / \mathrm{m}^{2} /$ year and then for $5 \mathrm{~g} \mathrm{~N} / \mathrm{m}^{2} /$ year (Table 2). Nitrogen has been correlated to lutein, $\beta$-carotene, and $\mathrm{Chl}$ with lower $\mathrm{N}$ grass pigment concentrations in the current When the $\mathrm{N}$ treatment levels were compared,

levels resulting in less pigment accumulation (Lefsrud et al., 2007). Under limited N, these pigments are reduced, resulting in leaf tissue chlorosis (Marschner, 1995). Previously, Lefsrud et al. (2007) reported a maximum lutein, $\beta$-carotene, and $\mathrm{Chl}$ accumulation occurring on hydroponically grown spinach at $52 \mathrm{mg} \mathrm{N} / \mathrm{L}$ for one cultivar but continuing to increase for the other reported cultivar. In a field study with winter wheat (Triticum aestivum L.), Follett et al. (1992) reported a $19 \%$ increase in Chl with an increase in $\mathrm{N}$ leaf concentration from 28 to $38 \mathrm{~g} \cdot \mathrm{kg}^{-1}$. Mangiafico and Guillard (2007) showed that increases in leaf $\mathrm{N}$ resulted in increased pigmentation for kentucky bluegrass. The highest levels of pigment accumulation (excluding $\beta$-carotene) in the current study occurred at the highest $\mathrm{N}$ treatment concentration (Table 2).

Sampling time had a significant effect on the accumulation of lutein $(P \leq 0.001)$, $\beta$-carotene $(P \leq 0.001)$, Chl a $(P \leq 0.001)$, and $\mathrm{Chl} b(P \leq 0.001)$. The sampling time and year of sampling had a significant impact on the accumulation rate of the pigments within the turfgrass (Table 3). However, no direct conclusions could be made because data from Year 1 resulted in an increase in pigments from the spring to the summer, whereas in Year 2, a decrease in pigmentation resulted. An observation between the 2 years of data was that Year 1 had higher rainfall, resulting in drought-stressed grass in Year 2. Year 1 had $78.9 \mathrm{~mm}$ of rainfall, whereas Year 2 had $46.2 \mathrm{~mm}$ of rainfall for $21 \mathrm{~d}$ before sampling with an expected average rainfall of $100.8 \mathrm{~mm}$ for the month of July (www.powellweather.com).

The impact of temperature on the quality of turfgrass has been reported by $\mathrm{Su}$ et al. (2007) and in carotenoid accumulation by McCurdy et al. (2008). Cui et al. (2006)

Table 2. Tissue carotenoid and chlorophyll pigments expressed on a fresh mass (FM) basis from three different nitrogen treatment levels $\left(5,14\right.$, and $27 \mathrm{~g} / \mathrm{m}^{2} /$ year). ${ }^{\mathrm{z}}$

\begin{tabular}{llccc}
\hline $\begin{array}{l}\text { Nitrogen treatment } \\
\left(\mathrm{g} / \mathrm{m}^{2} / \text { year }\right)\end{array}$ & \multicolumn{4}{c}{ Pigment concn $(\mathrm{mg} / 100 \mathrm{~g} \mathrm{FM})$} \\
\cline { 2 - 5 } & Lutein & $\beta$-carotene & Chlorophyll $a$ & Chlorophyll $b$ \\
\hline 5 & $45.2 \pm 2.2 \mathrm{a}$ & $19.7 \pm 1.0$ & $427.6 \pm 23.0 \mathrm{a}$ & $140.0 \pm 7.0 \mathrm{a}$ \\
14 & $48.9 \pm 2.0 \mathrm{ab}$ & $21.8 \pm 1.1$ & $458.0 \pm 21.8 \mathrm{ab}$ & $152.7 \pm 6.8 \mathrm{ab}$ \\
27 & $50.4 \pm 2.1 \mathrm{~b}$ & $22.0 \pm 1.2$ & $467.4 \pm 27.7 \mathrm{~b}$ & $157.3 \pm 7.3 \mathrm{~b}$ \\
\hline
\end{tabular}

${ }^{2}$ Data were combined from three replications of four grass cultivars (kentucky bluegrass 'Apollo', two hybrid heat-tolerant bluegrass 'Thermal Blue' and 'Dura Blue', and tall fescue 'Kentucky 31') with samples taken during the spring (March) and summer (July), repeated over 2 years.

Mean values $\pm \mathrm{SE}$.

Tukey's HSD significance at $P \leq 0.05$.

Table 3. Tissue carotenoid and chlorophyll pigments expressed on a fresh mass (FM) basis from samples taken during two seasons (spring and summer) over 2 years. ${ }^{2}$

\begin{tabular}{lcccr}
\hline & \multicolumn{4}{c}{ Pigment concn $(\mathrm{mg} / 100 \mathrm{~g}$ FM) } \\
\cline { 2 - 5 } Sample time & Lutein & $\beta$-carotene & Chlorophyll $a$ & Chlorophyll $b$ \\
\hline Spring Year 1 & $43.1 \pm 2.4 \mathrm{a}$ & $20.0 \pm 1.0 \mathrm{a}$ & $399.0 \pm 19.0 \mathrm{ab}$ & $128.9 \pm 6.7 \mathrm{a}$ \\
Summer Year 1 & $54.2 \pm 2.0 \mathrm{c}$ & $27.5 \pm 1.4 \mathrm{~b}$ & $594.4 \pm 23.2 \mathrm{c}$ & $191.8 \pm 5.4 \mathrm{c}$ \\
Spring Year 2 & $51.1 \pm 2.2 \mathrm{bc}$ & $19.2 \pm 1.0 \mathrm{a}$ & $449.5 \pm 25.9 \mathrm{~b}$ & $153.4 \pm 6.3 \mathrm{~b}$ \\
Summer Year 2 & $44.4 \pm 2.5 \mathrm{ab}$ & $17.8 \pm 0.7 \mathrm{a}$ & $360.9 \pm 17.3 \mathrm{a}$ & $125.9 \pm 6.5 \mathrm{a}$ \\
\hline
\end{tabular}

${ }^{\mathrm{z}}$ Data were combined from three replications of three nitrogen treatments $\left(5,14\right.$, and $27 \mathrm{~g} / \mathrm{m}^{2} /$ year) and four grass cultivars (kentucky bluegrass 'Apollo', two hybrid heat-tolerant bluegrass 'Thermal Blue' and 'Dura Blue', and tall fescue 'Kentucky 31').

Mean values $\pm \mathrm{SE}$.

Tukey's HSD significance at $P \leq 0.05$. reported that increased temperatures resulted in a decrease in Chl accumulation in two tall fescue cultivars. However, temperature was not considered a significant influencing factor with the average temperature $10 \mathrm{~d}$ before sampling being virtually identical in the spring at $10{ }^{\circ} \mathrm{C}$ for both years (maximum temperature was $24^{\circ} \mathrm{C}$ in 2006 and $21^{\circ} \mathrm{C}$ in 2007 , minimum was $-3{ }^{\circ} \mathrm{C}$ both years) and in the summer at $25^{\circ} \mathrm{C}$ in 2006 and $24^{\circ} \mathrm{C}$ in 2007 (maximum/minimum was $35^{\circ} \mathrm{C} / 18^{\circ} \mathrm{C}$ and $33{ }^{\circ} \mathrm{C} / 17^{\circ} \mathrm{C}$, respectively). Research by Jiang and Carrow (2005) on seashore paspalum (Paspalum vaginatum Swartz) and hybrid bermudagrass (Cynodon dactylon L. $\times C$. transvaalensis Burtt Davy) cultivars showed that increased drought stress resulted in decreases of $12 \%$ to $27 \%$ in turf quality expressed mainly as a reduction in plant pigmentation. This study investigated different species and varieties than our article, but the research by Jiang and Carrow (2005) support our explanation that a decrease of rainfall of $\approx 40 \%$ between the 2 years of the study could explain the significant decrease in plant pigmentation in our turfgrass varieties measured between years.

\section{Conclusion}

Four turfgrasses (kentucky bluegrass 'Apollo', two hybrid heat-tolerant bluegrass 'Thermal Blue' and 'Dura Blue', and tall fescue 'Kentucky 31') were analyzed for the pigment carotenoids lutein, $\beta$-carotene, and the two Chl $a$ and $b$ to determine the impact that genetics and environment have on pigment accumulation. Increasing $\mathrm{N}$ fertilization from 5 to $27 \mathrm{~g} \mathrm{~N} / \mathrm{m}^{2} /$ year resulted in a significant increase in lutein and Chl $a$ and $b$, but had no impact on the accumulation of $\beta$ carotene. A result of the analysis of the grass pigment concentrations is that the most heattolerant turfgrass in our study was the tall fescue 'Kentucky 31' and decreasing to 'Thermal Blue', 'Dura Blue', and finally 'Apollo'. However, the grasses with the highest pigmentation were the reverse with 'Apollo' having the largest concentration of pigments then 'Dura Blue', 'Thermal Blue', and finally 'Kentucky 31'. This result suggests that having elevated levels of lutein, $\beta$-carotene, and Chl $a$ and $b$ may actually result in less heat stress tolerance, possible as a result of increased partitioning of photosynthates to pigment production.

\section{Literature Cited}

Almela, L., J.M. López-Roca, M.E. Candela, and M.D. Alcázar. 1991. Carotenoid composition of new cultivars of red peppers for paprika. J. Agr. Food Chem. 39:1606-1609.

Beard, J.B. 1973. Cool season turfgrasses, p. 55131. In: Beard, J.B. (ed.). Turfgrass: Science and culture. Prentice Hall, Englewood Cliffs, NJ.

Bremer, D., K. Su, S. Keeley, and J. Fry. 2003. Drought resistance of two texas bluegrass hybrids compared with kentucky bluegrass and tall fescue. K-State Turfgrass Research SRP 911. Kansas State University Agricultural 
Experiment Station and Cooperative Extension Service. p. 67-77.

Bremer, D.J., K. Su, S.J. Keeley, and J.D. Fry. 2006. Performance in the transition zone of two hybrid bluegrasses compared with kentucky bluegrass and tall fescue. Applied Turfgrass Science. 10.1094/ATS-2006-0808-02-RS.

Cui, L.J., J.L. Li, Y.M. Fan, S. Xu, and Z. Zhang. 2006. High temperature effects on photosynthesis, PSII functionality and antioxidant activity of two Festuca arundinacea cultivars with different heat susceptibility. Bot. Stud. (Taipei, Taiwan) 47:61-69.

Daood, H.G., M. Vinkler, F. Márkus, E.A. Hebshi, and P.B. Biacs. 1996. Antioxidant vitamin content of spice red pepper (paprika) as affected by technological and varietal factors. Food Chem. 55:365-372.

de Azevedo, C.H. and D.B. Rodriguez-Amaya. 2005. Carotenoid composition of kale as influenced by maturity, season and minimal processing. J. Sci. Food Agr. 85:591-597.

Demmig-Adams, B., A.M. Gilmore, and W.W Adams III. 1996. In vivo functions of carotenoids in higher plants. FASEB J. 10:403-412.

Follett, R.H., R.F. Follett, and A.D. Halvorson. 1992. Use of a chlorophyll meter to evaluate the nitrogen status of dryland winter wheat. Commun. Soil Sci. Plant Anal. 23:687-697.

Frank, H.A. and R.J. Cogdell. 1996. Carotenoid in photosynthesis. Photochem. Photobiol. 63: 257-264.

Hochmuth, G.J., J.K. Brecht, and M.J. Bassett. 1999. Nitrogen fertilization to maximize carrot yield and quality on a sandy soil. HortScience 34:641-645.

Jiang, Y.W. and R.N. Carrow. 2005. Assessment of narrow-band canopy spectral reflectance and turfgrass performance under drought stress. HortScience 40:242-245.
Khachik, F., G.R. Beecher, and N.F. Whittaker. 1986. Separation, identification, and quantification of the major carotenoid and chlorophyll constituents in extracts of several green vegetables by liquid chromatography. J. Agr. Food Chem. 34:603-616.

Kopsell, D.A., D.E. Kopsell, M.G. Lefsrud, J. Curran-Celentano, and L.E. Dukach. 2004. Variation in lutein, beta-carotene, and chlorophyll concentrations among Brassica oleracea cultigens and seasons. HortScience 39:361-364.

Kurilich, A.C., G.J. Tsau, A. Brown, L. Howard, B.P. Klein, E.H. Jeffery, M. Kushad, M.A. Walig, and J.A. Juvik. 1999. Carotene, tocopherol, and ascorbate in subspecies of Brassica oleracea.. J. Agr. Food Chem. 47:1576-1581.

Lefsrud, M.G., D.A. Kopsell, D.E. Kopsell, and J. Curran-Celentano. 2005. Air temperature affects biomass and carotenoid pigment accumulation in kale and spinach grown in a controlled environment. HortScience 40:2026-2030.

Lefsrud, M.G., D.A. Kopsell, D.E. Kopsell, and J. Curran-Celentano. 2006. Irradiance affects biomass, elemental concentrations and carotenoid pigments in kale and spinach grown in a controlled environment. Physiol. Plant. 127:624-631.

Lefsrud, M.G., D.A. Kopsell, D.E. Kopsell, and J. Curran-Celentano. 2007. Nitrogen levels influence biomass, elemental accumulation, and pigment concentrations in spinach. J. Plant Nutr. 30:1-5.

Mangiafico, S.S. and K. Guillard. 2007. Coolseason turfgrass color and growth calibrated to leaf nitrogen. Crop Sci. 47:1217-1224.

Marschner, H. 1995. Mineral nutrition of higher plants. 2nd Ed. Academic Press Inc., New York, NY. pp. 231-254.

McCurdy, J.D., J.S. McElroy, D.A. Kopsell, C.E. Sams, and J.C. Sorochan. 2008. Effects of mesotrione on perennial ryegrass (Lolium per- enne L.) carotenoid concentrations under varying environmental conditions. J. Agr. Food Chem. 56:9133-9139.

McElroy, J.S., D.A. Kopsell, J.C. Sorochan, and C.E. Sams. 2006. Response of creeping bentgrass carotenoid composition to high and low irradiance. Crop Sci. 46:2606-2612.

Mills, H.A. and J.B. Jones, Jr. 1996. Plant analysis handbook II: A practical sampling, preparation, analysis, and interpretation guide. MicroMacro Publishing, Athens, GA.

Peng, C.L. and A.M. Gilmore. 2003. Contrasting changes of photosystem 2 efficiency in Arabidopsis xanthophylls mutants at room or low temperature under high irradiance stress. Photosynthetica 41:233-239.

Read, J.C., D. Walker, and B.W. Hipp. 1994. Potential of texas bluegrass $\times$ kentucky hybrids for turfgrass. Agronomy Abstracts. 86:183.

$\mathrm{Su}$, K., D.J. Bremer, S.J. Keeley, and J.D. Fry. 2007. Effects of high temperature and drought on a hybrid bluegrass compared with kentucky bluegrass and tall fescue. Crop Sci. 47:21522161 .

Taiz, L. and E. Zeiger. 1998. Plant physiology. 2nd Ed. Sinauer Associates, Inc., Sunderland, MA.

Teuton, T., J. Sorochan, C. Main, T. Samples, J. Parham, and T. Mueller. 2007. Hybrid bluegrass, kentucky bluegrass, and tall fescue response to nitrogen fertilization in the transition zone. HortScience 42:369-372.

Tracewell, C.A., J.S. Vrettos, J.A. Bautista, H.A. Frank, and G.W. Brudvig. 2001. Carotenoid photooxidation in photosystem II. Arch. Biochem. Biophys. 385:61-69.

Zhang, X.Z., E.H. Ervin, and R.E. Schmidt. 2005. The role of leaf pigment and antioxidant levels in UV-B resistance of dark- and light-green kentucky bluegrass cultivars. J. Amer. Soc. Hort. Sci. 130:836-841. 